\title{
A comparison of grass silages harvested at first, second and third cut on feed intake and milk production of dairy cows
}

\author{
Auvo Sairanen ${ }^{1}$, Sari Kajava ${ }^{1}$, Annu Palmio ${ }^{1}$ and Marketta Rinne ${ }^{2}$ \\ ${ }^{1}$ Natural Resources Institute Finland (Luke), FI-71750 Maaninka, Finland \\ ${ }^{2}$ Natural Resources Institute Finland (Luke), FI-31600 Jokioinen, Finland \\ e-mail: auvo.sairanen@luke.fi
}

\begin{abstract}
The objective of this study was to compare the milk production potential of subsequent first, second and third cuts of grass silage from the same sward in Northern latitudes. Three change-over design dairy cow feeding experiments were conducted during different years which differed markedly in weather conditions. The silages were supplemented with a cereal based concentrate (average concentrate proportion $431 \mathrm{~g} \mathrm{~kg}^{-1}$ diet dry matter). Feed intake and milk production was highest with first-cut and lowest with third-cut silage. The energy corrected milk yields averaged over three experiments were $35.0,33.2$ and $31.9 \mathrm{~kg} \mathrm{~d}^{-1}$ for first, second and third harvest silages, respectively. Respective dry matter intakes were $23.1,21.9$ and $20.7 \mathrm{~kg} \mathrm{~d}^{-1}$. Compared to analysed feed values, the average intake of third-cut silages was lower than expected. Due to the high risk of low intake potential of third-cut silages, they are not recommended for cows in early lactation if there are other silages available.
\end{abstract}

Key words: forage intake, forage quality, harvesting strategy, primary growth, regrowth

\section{Introduction}

Grass silage made typically of timothy and meadow fescue comprises over $50 \%$ of the diet dry matter (DM) in dairy cow feeding in Finland (Huhtamäki 2020). A three-cut harvesting strategy for silage is applicable in southern Finland whereas two silage cuts are typical in the northern Finland. Increased length of growing season due to global warming most probably moves the three-cut strategy slowly towards North. Three-cut strategy is recommended if the target is to maximize digestible grass yield over the whole growing season (Hyrkäs et al. 2015).

The high silage digestibility of a three-cut strategy is a consequence of early first cut and relatively short growing periods of the other two harvests. Despite of similar feed values based on laboratory analyses, the production responses to second-cut silages have been lower compared with primary growth (Heikkilä et al. 1998, Kuoppala et al. 2008, Pang et al. 2019). According to the meta-analysis of Huhtanen et al. (2007), regrowth silage consumption remained $0.44 \mathrm{~kg} \mathrm{DM} \mathrm{d}^{-1}$ lower than primary growth silage of similar composition. However, second-cut and third-cut silages were not separated in that analysis because of the limited amount of third-cut silages in the data set. The results reported by Sairanen et al. (2016) and Pang et al. (2021) suggest that production responses to third-cut silages do not fulfil the productive expectations, but systematic experimental evidence is scarce and the reasons for inferior performance of regrowth silages are still unknown.

It is very difficult to conduct unbiased comparisons between the different grass harvests. The effect of harvest includes changes in proportions of plant species in a multi-species sward and between proportions of vegetative and generative tillers, occurrence of plant diseases and weather conditions. Further, plant maturity (i.e. timing of cut within the harvest) plays a crucial role in determining the feed intake potential of grass as demonstrated e.g. by Rinne et al. (1999) within primary growth. The effect of plant maturity on feed intake and milk production has also been demonstrated for the second cut of silage, although to somewhat minor extent than for primary growth (Kuoppala et al. 2008). Thus, the choice of cutting time within the harvest may greatly affect the result of the comparisons over harvests. Further, the cutting time of the preceding harvest affects the development of later harvests within that particular growing season. A comprehensive way to study the effect of grass harvests on milk production would be to conduct series of experiments and make conclusions based on several trials. Optimally, a range of varying silage qualities would be made within each harvest, but the amount of resources required for such studies is very large. For example in the study of Kuoppala et al. (2008), two cutting times in primary growth were harvested twice in regrowth resulting in six different silages. Feeding them simultaneously in a feeding trial challenges the capacity of most experimental facilities. 
This study is focused on the feeding value of third-cut grass silage, which has rarely been studied. We hypothesized that both the intake and milk production are lower with the third-cut silage compared to first and second-cut silages even when taking into account the chemical characteristics of the silages.

\section{Material and methods \\ Experimental silages}

The study was conducted at Natural Resources Institute Finland (Luke) at Maaninka, Finland $\left(63^{\circ} 09.5^{\prime} \mathrm{N}, 027^{\circ} 18^{\prime} \mathrm{E}\right)$ and it included three separate experiments: experiment 1 (Exp 1) in 2011, experiment $2(\operatorname{Exp} 2)$ in 2016 and experiment $3(\operatorname{Exp} 3)$ in 2017. Each year included primary growth (H1), first regrowth $(\mathrm{H} 2)$ and second regrowth (H3) from the same swards within each year. The harvest dates were 12 June (H1), 26 July (H2) and 4 September $(\mathrm{H} 3)$ in Exp1, 5 June $(\mathrm{H} 1), 17$ July $(\mathrm{H} 2)$ and 31 August $(\mathrm{H} 3)$ in Exp 2 and 21 June (H1), 27 July (H2) and 25 September $(\mathrm{H} 3)$ in Exp 3. The harvest days were decided based on the target of 680-700 g digestible organic matter $\mathrm{kg}^{-1}$ silage DM and prevailing weather conditions according to the normal farming practices in the region.

The grass silages in Exp 1 and Exp 2 were harvested from a single field with an integrated round baler and wrapper using eight layers of stretch-plastic film. The grass silages in Exp 3 were harvested from seven separate fields with a precision chop harvester and stored in separate bunker silos. The experimental fields were sown with a mixture of timothy (Phleum pratense L.) and meadow fescue (Festuca pratensis Huds.). Meadow fescue was the dominant species in the experimental fields (80:20 seed ratio). The age of lays varied between 1 to 4 years. The fields were fertilized with $90 \mathrm{~kg} \mathrm{~N}$ per hectare in early May and after first cut, and with $50 \mathrm{~kg} \mathrm{~N}$ after the first and the second cut. All silages were treated with a formic acid-based additive (AIV 2 Plus, Eastman, Oulu, Finland) at a target rate of 5 I litres per ton of fresh forage.

\section{Animals, diets and experimental design}

The cows were kept in a loose-house dairy barn, offered grass silage ad libitum and given free access to drinking water. Individual silage or total mixed ration (TMR) intake was measured using automated troughs (Insentec BV, Marknesse, the Netherlands) and concentrate intake with automated feeding stations (Pellon Ltd., Ylihärmä, Finland). Live weight of the cows was measured using an automated scale placed in concentrate feeding stations in Exp 1 and Exp 2 while Exp 3 did not include live weight measurements. The cows were milked twice a day in a herringbone milking parlour at approximately 0600 and $1500 \mathrm{~h}$. The use of animals in scientific experimentation was in line with Directive 2010/63/EU. No invasive research methods were used so that a formal license was not required according to the National Ethics Committee (Hämeenlinna, Finland).

Experiment 1 included 34 dairy cows (Holstein $n=27$ and Nordic Red $n=7$ ). The average pre-experimental milk yield of them was 33.4 (SD 6.63) kg and days in milk (DIM) 98 (SD 47.4). The experiment included three silages supplemented with 9, 11 or $13 \mathrm{~kg}$ of pelleted commercial concentrate (Table 1). The silages and concentrates were fed separately. Cows were divided into four blocks according to their pre-experimental milk yield and DIM. The experiment was conducted as an incomplete cross-over design with four periods and nine dietary treatments.

Experiment 2 included 45 dairy cows (Holstein $n=32$ and Nordic Red $n=13$ ). The average pre-experimental milk yield of them was 31.6 (SD 5.54) kg and DIM 140 (SD 30.9). The diets were fed as TMR where the target forage to concentrate ratio was 550:450 on DM basis. The experimental diets and their chemical composition are presented in Table 1. In addition, the cows received mineral mixture according to feeding recommendations and $1.5 \mathrm{~kg}$ barley from an automated concentrate feeder. The cows were divided into four blocks according to their preexperiment milk yield, DIM and parity. The first block included primiparous cows ( $n=9)$. Other three blocks included high $(n=12)$, moderate $(n=12)$ and low yielding multiparous cows $(n=12)$. The experiment was conducted as an incomplete cross-over design with two periods and three dietary treatments.

Experiment 3 was conducted using the same design as Exp 2. The number of cows was 48 (Holstein $n=36$ and Nordic Red $\mathrm{n}=12$ ). The average pre-experiment milk yield was 33.1 (SD 6.48) kg and DIM 129 (SD 58.5). The diets were fed as TMR where the target forage to concentrate ratio was 600:400 on DM basis (Table 1). In all experiments, the length of the period was $21 \mathrm{~d}$ including 7 days of data collection in the end of each period. 
Table 1. The ingredients of diets (TMR in Experiments 2 and 3) and their nutritional composition for first (H1), second (H2) and third cut (H3) of grass silage.

\begin{tabular}{|c|c|c|c|c|c|c|c|c|c|}
\hline & \multicolumn{3}{|c|}{ Experiment 1} & \multicolumn{3}{|c|}{ Experiment 2} & \multicolumn{3}{|c|}{ Experiment 3} \\
\hline & $\mathrm{H} 1$ & $\mathrm{H} 2$ & H3 & $\mathrm{H} 1$ & $\mathrm{H} 2$ & H3 & $\mathrm{H} 1$ & $\mathrm{H} 2$ & $\mathrm{H} 3$ \\
\hline \multicolumn{10}{|l|}{ Ingredients, $\mathrm{g} \mathrm{kg}^{-1} \mathrm{DM}^{1)}$} \\
\hline Silage & 581 & 578 & 561 & 538 & 544 & 528 & 585 & 598 & 606 \\
\hline Barley & 105 & 106 & 110 & 365 & 361 & 374 & 320 & 309 & 304 \\
\hline Oats & 105 & 106 & 110 & & & & & & \\
\hline Molassed sugar beet pulp & 105 & 106 & 110 & & & & & & \\
\hline Rapeseed meal & 92 & 93 & 97 & 82 & 80 & 83 & 80 & 78 & 75 \\
\hline Minerals ${ }^{2)}$ & 13 & 13 & 13 & 15 & 15 & 15 & 15 & 15 & 15 \\
\hline \multicolumn{10}{|l|}{ In the diet, $\mathrm{g} \mathrm{kg}^{-1} \mathrm{DM}$} \\
\hline Crude protein & 180 & 188 & 188 & 164 & 163 & 157 & 189 & 166 & 161 \\
\hline Neutral detergent fibre & 429 & 420 & 403 & 384 & 393 & 372 & 362 & 392 & 376 \\
\hline$M E^{3)}, \mathrm{MJ} \mathrm{kg}^{-1} \mathrm{DM}$ & 11.4 & 11.2 & 11.6 & 11.9 & 11.4 & 11.8 & 12.0 & 11.2 & 11.4 \\
\hline Protein balance in the rumen & 37.2 & 45.9 & 41.6 & 41.7 & 29.6 & 23.1 & 43.9 & 30.6 & 25.5 \\
\hline
\end{tabular}

1) $\mathrm{DM}=$ Dry matter; ${ }^{2)}$ Lypsykivennäinen (Hankkija Ltd., Hyvinkää, Finland); ${ }^{3)} \mathrm{ME}=$ Metabolizable energy

\section{Data and sample collection, and chemical analysis}

The milk yield was recorded at every milking and data from last seven days of each period was used for calculation of the results. Milk samples were collected from four consecutive milkings during the data collection period, and analysed separately for fat, protein and urea using an infrared analyser (Milcoscan FT6000, Valio Ltd., Seinäjoki, Finland). The milk composition was determined based on the weighted means of the a.m. and p.m. milkings. The energy corrected milk (ECM) yield was calculated according to Sjaunja et al. (1990).

The DM content of TMR was measured daily during the data collection period. Silages and concentrates were sampled separately before TMR mixing during the data collection period, pooled per each experimental period and stored at $-20^{\circ} \mathrm{C}$.

The DM content of the feed samples was determined by drying the samples at $+105^{\circ} \mathrm{C}$ for $20 \mathrm{~h}$. Feed samples for chemical analysis were dried at $+60^{\circ} \mathrm{C}$ until dry and analysed for ash (AOAC 1990, No 942.05), nitrogen with the Dumas method using a Leco FP 428 analyser (crude protein [CP] content was calculates as N content $\times 6.25$ ), and NDF according to Van Soest et al. (1991) using Na-sulphite, without amylase for forages and presented ash-free. The silage samples were analysed for $\mathrm{pH}$, volatile fatty acids (VFA, Huhtanen et al. 1998), lactic acid (Haacker et al. 1983), ammonia N (McCullough 1967), water soluble N (AOAC 1990, No 984.13), water soluble carbohydrates (Somogyi 1945) and in vitro organic matter pepsin-cellulase solubility (OMS) according to Nousiainen et al. (2003). The in vitro digestibility results were calculated with correction equations to convert OMS values into in vivo digestibility using equations based on a data set comprising of Finnish in vivo digestibility trials (Huhtanen et al. 2006) using separate equations for primary growth and regrowth silages. The relative intake potential of silage DM (SDMI index) was calculated according to Huhtanen et al. (2007).

The temperature and rainfall data were obtained from meteorological stations of the Finnish Meteorological Institute located in close proximity of the experimental fields.

\section{Calculations and statistical analysis}

The metabolizable energy (ME) content of the concentrates was calculated based on separate digestible nutrients while silage ME content was calculated based on the digestible organic matter (DOM) content according to the Finnish feed evaluation system (Luke 2021). The ME intake of the cows was calculated taking into account the effects of diet composition and intake level according to Luke (2021). Metabolizable protein (MP) expressed as amino acids absorbed from the small intestine and protein balance in the rumen were calculated according to Luke 
(2021). The efficiency of utilization of ME for milk production $\left(k_{1}\right)$ was calculated as ECM $\times 3.14$ / (ME intake - ME for maintenance) and MP utilization as milk protein output / (MP intake - MP for maintenance). The MP balance was calculated as MP requirement - (MP for maintenance + MP for milk production).

Data from the three experiments were analysed separately using SAS MIXED procedure (version 9.4; SAS Institute Inc., Cary, NC, USA) including period, harvesting time and block as fixed variables and animal as a random variable. The harvesting time $\times$ block interaction was also tested but it was rejected from the final model due non-significant differences. The significance of the pairwise differences between harvests was analysed with the Tukey test using a $5 \%$ error rate.

\section{Results}

\section{Experimental silages}

The start of the growing season in Exp 1 was typical in Finland (Table 2). The timing of the second harvest was slightly delayed due to rainy weather conditions, but still within an acceptable time frame. There were no weather challenges during late summer and the harvests were conducted as planned. The weather was challenging during harvesting of the silages for Exp 2. Due to precipitation the pre-wilting times of $\mathrm{H} 1$ and $\mathrm{H} 2$ especially in Exp 2 were longer than recommended. Rainy weather also continued during autumn and $\mathrm{H} 3$ was harvested between showers. In general, despite of the weather challenges, the timing of harvests was typical for a three-cut strategy. The weather was also cool and rainy during the harvest of $\mathrm{H} 2$ and $\mathrm{H} 3$ in Exp 3 . The effective temperate sum was the lowest in Exp 3 despite of the longest growing period in calendar days among the experiments. The harvest of $\mathrm{H} 2$ was delayed which also postponed $\mathrm{H} 3$.

Table 2. Dates of harvests, prewilting times (h), growing days and descriptive weather statistics during the growing seasons for first $(\mathrm{H} 1)$, second $(\mathrm{H} 2)$ and third cut $(\mathrm{H} 3)$ of grass silage across different years.

\begin{tabular}{|c|c|c|c|c|c|c|c|c|c|}
\hline & \multicolumn{3}{|c|}{ Experiment 1, year 2011} & \multicolumn{3}{|c|}{ Experiment 2, year 2016} & \multicolumn{3}{|c|}{ Experiment 3, year 2017} \\
\hline & $\mathrm{H} 1$ & $\mathrm{H} 2$ & H3 & $\mathrm{H} 1$ & $\mathrm{H} 2$ & H3 & $\mathrm{H} 1$ & $\mathrm{H} 2$ & $\mathrm{H} 3$ \\
\hline Date of harvest & 12 June & 26 July & 4 Sept & 5 June & 17 July & 31 August & 21 June & 27 July & 25 Sept \\
\hline Prewilting time, $\mathrm{h}$ & 6 & 6 & 20 & 30 & 48 & 6 & 20 & 20 & 20 \\
\hline Effective temperature sum, ${ }^{\circ} \mathrm{C} \mathrm{d}^{1,2)}$ & 321 & 561 & 412 & 304 & 440 & 49 & 233 & 332 & 481 \\
\hline Growing days ${ }^{2)}$ & 50 & 44 & 40 & 40 & 42 & 45 & 35 & 36 & 60 \\
\hline Precipitation, $\mathrm{mm}^{2)}$ & 61 & 170 & 90 & 28 & 137 & 91 & 35 & 114 & 140 \\
\hline Average temperature, ${ }^{\circ} \mathrm{C}^{2)}$ & 11.1 & 17.8 & 15.3 & 12.4 & 15.5 & 16.2 & 11.4 & 14.2 & 12.9 \\
\hline
\end{tabular}

1) Accumulated temperature over $5{ }^{\circ} \mathrm{C}$ since the onset of the growing season; ${ }^{2)}$ Since the onset of growing season for $\mathrm{H} 1$, and since previous harvest for $\mathrm{H} 2$ and $\mathrm{H} 3$

Table 3 presents the chemical composition of the experimental silages. In Exp 1 the silage quality and nutritional values were comparable between the harvests except for the energy content which was the lowest in $\mathrm{H} 2$ resulting in the lowest SDMI index. The NDF content in H3 was high for an autumn harvested grass. Both VFA and ammonia proportions were relatively high in all silages in Exp 1 indicating slightly impaired fermentation quality. In Exp 2 the quality of $\mathrm{H} 1$ was superior compared with regrowth silages. Silage $\mathrm{H} 2$ had increased ammonia N and VFA content indicating slight problems in preservation. The DM content of $\mathrm{H} 3$ was exceptionally low due to humid weather conditions around harvest.

In Exp 3, the amount of total acids was slightly elevated in all silages, but the fermentation quality was acceptable excluding the proportion of butyric acid of $\mathrm{H} 2$. However, the silage had no bad smell. The energy and CP contents and SDMI index were the highest in $\mathrm{H} 1$ silage. Again, the DM content was lowest in H3. Low D-value in $\mathrm{H} 2$ and low DM content in $\mathrm{H} 3$ decreased their SDMI index values. 
Table 3. Chemical composition of the first $(\mathrm{H} 1)$, second $(\mathrm{H} 2)$ and third cut $(\mathrm{H} 3)$ grass silages across different years.

\begin{tabular}{|c|c|c|c|c|c|c|c|c|c|}
\hline & \multicolumn{3}{|c|}{ Experiment 1} & \multicolumn{3}{|c|}{ Experiment 2} & \multicolumn{3}{|c|}{ Experiment 3} \\
\hline & $\mathrm{H} 1$ & $\mathrm{H} 2$ & H3 & $\mathrm{H} 1$ & $\mathrm{H} 2$ & $\mathrm{H} 3$ & $\mathrm{H} 1$ & $\mathrm{H} 2$ & H3 \\
\hline Dry matter (DM), $\mathrm{g} \mathrm{kg}^{-1}$ & 226 & 249 & 242 & 307 & 217 & 177 & 264 & 212 & 186 \\
\hline $\mathrm{pH}$ & 4.59 & 4.60 & 4.65 & 4.73 & 4.29 & 4.20 & 4.07 & 4.06 & 3.89 \\
\hline \multicolumn{10}{|l|}{ In DM, $\mathrm{g} \mathrm{kg}^{-1}$} \\
\hline Ash & 84 & 89 & 94 & 86 & 103 & 107 & 93 & 102 & 110 \\
\hline Crude protein & 176 & 189 & 189 & 169 & 168 & 157 & 205 & 166 & 158 \\
\hline Water soluble carbohydrates & 50 & 40 & 54 & 90 & 66 & 105 & 19 & 11 & 64 \\
\hline Neutral detergent fibre & 563 & 549 & 529 & 521 & 531 & 503 & 466 & 510 & 482 \\
\hline Lactic acid & 43 & 48 & 48 & 27 & 42 & 35 & 65 & 61 & 84 \\
\hline Acetic acid & 15.6 & 23.7 & 19.2 & 10.2 & 16.2 & 8.8 & 17.9 & 19.0 & 13.0 \\
\hline Propionic acid & 0.79 & 0.65 & 0.46 & 0.42 & 0.62 & 0.57 & 0.19 & 0.52 & 0.19 \\
\hline Butyric acid & 0.62 & 0.24 & 0.18 & 0.42 & 0.39 & 0.20 & 0.15 & 2.66 & 0.05 \\
\hline Total fermentation acids & 78 & 91 & 86 & 51 & 79 & 65 & 98 & 100 & 116 \\
\hline Soluble $\mathrm{N}, \mathrm{g} \mathrm{kg}^{-1} \mathrm{~N}$ & 705 & 594 & 594 & 608 & 603 & 513 & 570 & 519 & 493 \\
\hline Ammonium $\mathrm{N}, \mathrm{g} \mathrm{kg}^{-1} \mathrm{~N}$ & 108 & 109 & 102 & 64 & 104 & 58 & 42 & 60 & 50 \\
\hline Metabolizable energy, $\mathrm{MJ} \mathrm{kg}^{-1} \mathrm{DM}$ & 10.9 & 10.6 & 11.2 & 11.2 & 10.4 & 11.0 & 11.7 & 10.5 & 10.7 \\
\hline SDMI index ${ }^{1)}$ & 98 & 90 & 99 & 112 & 86 & 92 & 109 & 84 & 83 \\
\hline D-value, $\mathrm{g} \mathrm{kg}^{-1}$ & 679 & 663 & 700 & 700 & 650 & 688 & 731 & 656 & 669 \\
\hline Predicted D-value, $\mathrm{g} \mathrm{kg}^{-1,2)}$ & 679 & 664 & 717 & 699 & 678 & 704 & 742 & 699 & 702 \\
\hline
\end{tabular}

1) SDMI index = The relative intake potential of silage DM (Huhtanen et al. 2007); ${ }^{2)}$ Predicted D-value according to Hyrkäs et al. (2018)

\section{Intake, milk performance and energy utilisation}

The lowest silage intake was observed when $\mathrm{H} 3$ was fed in all experiments (Table 4). The intake of H3 was especially low in Exp 3. There was no effect of harvest on DM intake between $\mathrm{H} 2$ and $\mathrm{H} 3$ in Exp 2 because of slightly elevated concentrate proportion in H3. Exp 2 was conducted using baled silage which varied in DM content between bales resulting in variable concentrate proportion in the TMRs. Exp 1 was conducted with separate silage and concentrate feeding and the amount on concentrate intake was fixed. Low intake of H3 also decreased MP, ME and NDF intake in Exp 3. Nutrient intake was typically highest with H1 diets. Both the NDF intake and NDF proportion in the diet were always lowest in $\mathrm{H} 3$ silages due to low NDF content of $\mathrm{H} 3$.

The lowest milk yield was observed with H3 in Exp 1 and Exp 3 (Table 5), while in Exp 2 the lowest milk yield was observed with $\mathrm{H} 2$. The effect of harvest on milk protein and fat content was not clear but typically their contents were lower with regrowth silages compared with $\mathrm{H} 1$. Milk urea content generally followed the grass CP content and the differences between the harvests were most clear in Exp 3.

The differences in feed conversion rate, expressed as produced ECM per DM intake, are reported in Table 6. Typically, milk production increased in line with feed intake while the feed conversion rate numerically decreased. This can be seen most clearly in Exp 3 where the numerically highest DM conversion was observed with $\mathrm{H} 3(p=0.05)$. In general, $\mathrm{H} 1$ had slightly lower feed conversion rate compared with regrowth silages except for $\mathrm{H} 2$ in Exp 2.

The efficiency of ME utilization (MJ ME per kg ECM produced) decreased concurrently with increasing ME intake. The ME balance followed ME intake so that the highest ME balance was achieved with $\mathrm{H} 1$ whereas the $\mathrm{H} 3$ produced the most negative ME balance in Exp 3. Numerically the changes in live weight followed ME balance but the differences were not significant. Unfortunately, for Exp 3 live weight changes of the animals were not available.

The nitrogen utilization reflected changes in silage CP concentration and highest utilisation was observed with $\mathrm{H} 3$ in Exp 2 and lowest utilization with silages in Exp 1. 
Table 4. Feed and nutrient Intake of cows offered first ( $\mathrm{H} 1)$, second ( $\mathrm{H} 2)$ and third cut (H3) grass silages across different years.

\begin{tabular}{|c|c|c|c|c|c|c|c|c|c|c|c|c|c|c|c|}
\hline & \multicolumn{5}{|c|}{ Experiment 1} & \multicolumn{5}{|c|}{ Experiment 2} & \multicolumn{5}{|c|}{ Experiment 3} \\
\hline & $\mathrm{H} 1$ & $\mathrm{H} 2$ & H3 & $\mathrm{SEM}^{1)}$ & $p$-value & $\mathrm{H} 1$ & $\mathrm{H} 2$ & H3 & SEM & $p$-value & $\mathrm{H} 1$ & $\mathrm{H} 2$ & H3 & SEM & $p$-value \\
\hline \multicolumn{16}{|l|}{ Feed dry matter (DM) intake, $\mathrm{kg} \mathrm{d}^{-1}$} \\
\hline Silage & $13.3^{\mathrm{a}}$ & $13.2^{\mathrm{a}}$ & $12.3^{b}$ & 0.22 & $<0.001$ & $12.4^{\mathrm{a}}$ & $12.0^{\mathrm{b}}$ & $11.6^{c}$ & 0.18 & $<0.001$ & $14.1^{\mathrm{a}}$ & $12.9^{\mathrm{b}}$ & $11.4^{\mathrm{c}}$ & 0.21 & $<0.001$ \\
\hline Concentrate & 9.6 & 9.6 & 9.6 & - & & $10.0^{\mathrm{a}}$ & $9.5^{b}$ & $9.8^{c}$ & 0.15 & $<0.001$ & $10.0^{\mathrm{a}}$ & $8.6^{\mathrm{b}}$ & $7.4^{c}$ & 0.15 & $<0.001$ \\
\hline Total & $22.9^{\mathrm{a}}$ & $22.8^{\mathrm{a}}$ & $21.9^{\mathrm{b}}$ & 0.22 & $<0.001$ & $22.4^{\mathrm{a}}$ & $21.5^{\mathrm{b}}$ & $21.4^{\mathrm{b}}$ & 0.32 & $<0.001$ & $24.1^{\mathrm{a}}$ & $21.5^{\mathrm{b}}$ & $18.7^{c}$ & 0.35 & $<0.001$ \\
\hline \multicolumn{16}{|l|}{ Nutrient intake, $\mathrm{d}^{-1}$} \\
\hline Organic matter, kg & $21.1^{\mathrm{a}}$ & $20.9^{\mathrm{a}}$ & $20.0^{\mathrm{b}}$ & 0.20 & $<0.001$ & $20.9^{a}$ & $20.0^{\mathrm{b}}$ & $19.8^{\mathrm{b}}$ & 0.29 & $<0.001$ & $22.1^{\mathrm{a}}$ & $19.6^{\mathrm{b}}$ & $17.0^{c}$ & 0.53 & $<0.001$ \\
\hline Crude protein, kg & $4.01^{\mathrm{c}}$ & $4.33^{\mathrm{a}}$ & $4.13^{b}$ & 0.04 & $<0.001$ & $3.69^{\mathrm{a}}$ & $3.51^{\mathrm{b}}$ & $3.36^{c}$ & 0.057 & $<0.001$ & 4.55 & 3.55 & 3.0 & 0.06 & $<0.001$ \\
\hline Neutral detergent fibre, $\mathrm{kg}$ & $9.84^{\mathrm{a}}$ & $9.59^{b}$ & $8.84^{c}$ & 0.119 & $<0.001$ & $8.63^{\mathrm{a}}$ & $8.45^{\mathrm{b}}$ & $7.96^{\mathrm{b}}$ & 0.12 & $<0.001$ & $10.3^{\mathrm{a}}$ & $9.7^{b}$ & $8.2^{\mathrm{c}}$ & 0.15 & $<0.001$ \\
\hline Metabolisable protein, $\mathrm{g}$ & $2.07^{\mathrm{a}}$ & $2.06^{\mathrm{a}}$ & $2.03^{b}$ & 0.185 & $<0.01$ & $2.16^{\mathrm{a}}$ & $2.00^{\mathrm{b}}$ & $2.03^{b}$ & 0.03 & $<0.001$ & $2.39^{\mathrm{a}}$ & $1.98^{\mathrm{b}}$ & $1.73^{c}$ & 0.03 & $<0.001$ \\
\hline Metabolizable energy ${ }^{21}, \mathrm{MJ} \mathrm{d}^{-1}$ & $244^{\mathrm{a}}$ & $241^{\mathrm{b}}$ & $238^{\mathrm{c}}$ & 2.0 & $<0.01$ & $247^{a}$ & $230^{\mathrm{b}}$ & $234^{c}$ & 3.2 & $<0.001$ & $266^{\mathrm{a}}$ & $228^{\mathrm{b}}$ & $203^{c}$ & 3.5 & $<0.001$ \\
\hline $\mathrm{PBV}^{3)}, \mathrm{g}(\mathrm{kg} \mathrm{DM})^{-1}$ & $37.2^{\mathrm{a}}$ & $45.9^{\mathrm{b}}$ & $41.6^{c}$ & 0.39 & $<0.01$ & $41.7^{\mathrm{a}}$ & $29.6^{\mathrm{b}}$ & $23.1^{\mathrm{c}}$ & 0.23 & $<0.001$ & $43.9^{\mathrm{a}}$ & $30.6^{b}$ & $25.5^{c}$ & 0.36 & $<0.001$ \\
\hline
\end{tabular}

${ }^{1)}$ SEM = Standard error of the mean; ${ }^{2)}$ Metabolizable energy intake was calculated according to Luke (2021) taking into account the effects of diet composition and intake level. ${ }^{3)}$ Protein balance in the rumen; ${ }^{a, b, c}$ Means in a row within each experiment without a common superscript letter are significantly different from each other $(p<0.05)$ according to the Tukey test.

Table 5. Milk production of cows offered first (H1), second ( $\mathrm{H} 2)$ and third cut $(\mathrm{H} 3)$ grass silages across different years.

\begin{tabular}{|c|c|c|c|c|c|c|c|c|c|c|c|c|c|c|c|}
\hline & \multicolumn{5}{|c|}{ Experiment 1} & \multicolumn{5}{|c|}{ Experiment 2} & \multicolumn{5}{|c|}{ Experiment 3} \\
\hline & $\mathrm{H} 1$ & $\mathrm{H} 2$ & H3 & SEM $^{1)}$ & $p$-value & $\mathrm{H} 1$ & $\mathrm{H} 2$ & $\mathrm{H} 3$ & SEM & $p$-value & $\mathrm{H} 1$ & $\mathrm{H} 2$ & $\mathrm{H} 3$ & SEM & $p$-value \\
\hline \multicolumn{16}{|l|}{ Production $\mathrm{kg} \mathrm{d}^{-1}$} \\
\hline Milk & $34.2^{\mathrm{a}}$ & $34.5^{\mathrm{a}}$ & $33.5^{\mathrm{b}}$ & 0.61 & $<0.01$ & $30.0^{\mathrm{a}}$ & $28.4^{\mathrm{b}}$ & $30.0^{\mathrm{a}}$ & 0.38 & $<0.001$ & $33.4^{\mathrm{a}}$ & $30.7^{\mathrm{b}}$ & $27.2^{\mathrm{c}}$ & 0.70 & $<0.001$ \\
\hline $\mathrm{ECM}^{2)}$ & $33.7^{\mathrm{a}}$ & $34.0^{\mathrm{a}}$ & $33.3^{b}$ & 0.59 & $<0.05$ & $34.2^{\mathrm{a}}$ & $31.9^{\mathrm{b}}$ & $32.8^{c}$ & 0.49 & $<0.001$ & $36.7^{\mathrm{a}}$ & $33.4^{\mathrm{b}}$ & $29.6^{c}$ & 0.63 & 0.001 \\
\hline Protein & $1.186^{\mathrm{a}}$ & $1.176^{\mathrm{a}}$ & $1.142^{\mathrm{b}}$ & 0.0209 & $<0.01$ & 1.138 & 1.056 & 1.135 & 0.0169 & ns & $1.227^{\mathrm{a}}$ & $1.091^{b}$ & $0.9481^{c}$ & 0.0218 & $<0.001$ \\
\hline Fat & 1.349 & 1.371 & 1.337 & 0.0307 & ns & $1.482^{\mathrm{a}}$ & $1.369^{b}$ & $1.366^{\mathrm{b}}$ & 0.0259 & $<0.001$ & $1.567^{\mathrm{a}}$ & $1.433^{\mathrm{b}}$ & $1.286^{c}$ & 0.0304 & $<0.001$ \\
\hline \multicolumn{16}{|c|}{ Milk composition, $\mathrm{g} \mathrm{kg}^{-1}$} \\
\hline Protein & 34.9 & 34.3 & 34.2 & 0.35 & ns & $38.2^{\mathrm{a}}$ & $37.5^{\mathrm{b}}$ & $38.0^{\mathrm{ab}}$ & 0.31 & $<0.01$ & $37.0^{\mathrm{a}}$ & $35.9^{\mathrm{b}}$ & $35.3^{\mathrm{b}}$ & 0.47 & $<0.001$ \\
\hline Fat & 39.7 & 40.0 & 40.0 & 0.57 & ns & $49.8^{\mathrm{a}}$ & $48.7^{\mathrm{a}}$ & $45.9^{b}$ & 0.72 & $<0.001$ & 47.6 & 47.2 & 47.6 & 0.95 & ns \\
\hline Milk urea, $\mathrm{mg} \mathrm{dl}^{-1}$ & $32.7^{c}$ & $37.6^{\mathrm{a}}$ & $34.5^{b}$ & 0.88 & $<0.001$ & $23^{b}$ & $27^{c}$ & $21^{c}$ & 0.6 & $<0.001$ & $31^{\mathrm{a}}$ & $26^{b}$ & $24^{c}$ & 0.6 & $<0.001$ \\
\hline
\end{tabular}

to the Tukey test. 
Table 6. Efficiency of milk production of dairy cows fed first (H1), second ( $\mathrm{H} 2)$ and third cut (H3) grass silages across different years.

\begin{tabular}{|c|c|c|c|c|c|c|c|c|c|c|c|c|c|c|c|}
\hline & \multicolumn{5}{|c|}{ Experiment 1} & \multicolumn{5}{|c|}{ Experiment 2} & \multicolumn{5}{|c|}{ Experiment 3} \\
\hline & $\mathrm{H} 1$ & $\mathrm{H} 2$ & $\mathrm{H} 3$ & SEM $^{1)}$ & $p$-value & $\mathrm{H} 1$ & $\mathrm{H} 2$ & H3 & SEM & $p$-value & $\mathrm{H} 1$ & $\mathrm{H} 2$ & $\mathrm{H} 3$ & SEM & $p$-value \\
\hline $\mathrm{kg} \mathrm{ECM}^{2)} \mathrm{kg}^{-1} \mathrm{DM}^{3)}$ intake & $1.49^{\mathrm{b}}$ & $1.50^{\mathrm{a}}$ & $1.51^{\mathrm{a}}$ & 0.023 & 0.06 & $1.52^{\mathrm{a}}$ & $1.48^{\mathrm{b}}$ & $1.53^{\mathrm{a}}$ & 0.016 & $<0.01$ & $1.51^{\mathrm{b}}$ & $1.54^{b}$ & $1.56^{\mathrm{a}}$ & 0.027 & 0.05 \\
\hline $\mathrm{MJ} \mathrm{ME}^{4}{ }^{4} \mathrm{~kg}^{-1} \mathrm{ECM}$ & 5.28 & 5.20 & 5.18 & 0.103 & ns & $5.29^{\mathrm{a}}$ & $5.15^{b}$ & $5.12^{\mathrm{b}}$ & 0.062 & $<0.01$ & $5.48^{\mathrm{a}}$ & $4.87^{\mathrm{b}}$ & $4.71^{\mathrm{c}}$ & 0.097 & $<0.001$ \\
\hline ME balance & 1.51 & -0.81 & -1.48 & 3.008 & ns & $4.1^{\mathrm{a}}$ & $0.1^{b}$ & $-1.1^{b}$ & 2.03 & $<0.05$ & $10.7^{\mathrm{a}}$ & $-10.1^{b}$ & $-15.0^{\mathrm{b}}$ & 3.06 & $<0.001$ \\
\hline$k_{1}^{5)}$ & 0.606 & 0.613 & 0.614 & 0.0010 & ns & $0.596^{\mathrm{b}}$ & $0.613^{\mathrm{a}}$ & $0.615^{\mathrm{a}}$ & 0.0073 & $<0.01$ & $0.578^{b}$ & $0.644^{\mathrm{a}}$ & $0.669^{\mathrm{a}}$ & 0.0106 & $<0.001$ \\
\hline Live weight, kg & $660^{\mathrm{a}}$ & $647^{b}$ & $640^{b}$ & 10.9 & $<0.01$ & 653 & 650 & 649 & 7.5 & ns & - & - & - & & \\
\hline $\mathrm{MP}^{6)}$ balance, $\mathrm{g} \mathrm{d}^{-1}$ & -162 & -147 & -132 & 21.8 & ns & $0^{\mathrm{a}}$ & $-23^{\mathrm{a}}$ & $-100^{b}$ & 18.6 & $<0.001$ & $97^{\mathrm{a}}$ & $-89^{b}$ & $-105^{b}$ & 28.5 & $<0.001$ \\
\hline Milk N/N intake & $0.284^{a}$ & $0.269^{b}$ & $0.274^{b}$ & 0.0036 & $<0.001$ & $0.303^{b}$ & $0.300^{b}$ & $0.332^{\mathrm{a}}$ & 0.0039 & $<0.001$ & $0.264^{b}$ & $0.303^{a}$ & $0.308^{\mathrm{a}}$ & 0.0058 & $<0.001$ \\
\hline
\end{tabular}

1) $\mathrm{SEM}=$ standard error of the mean; ${ }^{2)} \mathrm{ECM}=$ energy corrected milk; ${ }^{3)} \mathrm{DM}=$ dry matter; ${ }^{4)} \mathrm{ME}=$ metabolizable energy; ${ }^{5}$ k = efficiency of ME utilization for milk production; ${ }^{6)} \mathrm{MP}=$ metabolizable protein, calculated according to Luke (2021); a, , c Means in a row within each experiment without a common superscript letter are significantly different from each other ( $p<0.05$ ) according to the Tukey test. 


\section{Discussion}

The focus in this research was to compare third-cut silage with first and second cuts. According to unpublished statistics of Finnish dairy farm silages analysed by Valio Ltd. (Helsinki, Finland), the D-values were 684, 666 and 682 $\mathrm{g} \mathrm{kg} \mathrm{DM}^{-1}$ for first, second and third-cut silages, respectively, during 2015-2020. The number of analysed samples in the dataset has been approximately 27000 per year. The main differences between the harvests have been the lower DM and NDF contents in third-cut silages compared with first and second cut, and the lowest D-value in second-cut silages. The analyses of the current experimental silages were in line with the Valio dataset. The lower DM content of third cut silages is linked with the increasing air humidity and shorter day length in the autumn.

The fast decline of grass digestibility in primary growth harvest and subsequent decrease in milk production potential has been well established under Finnish conditions (Rinne et al. 1999, Kuoppala et al. 2008). This has led to the need to predict the D-value, which has been shown to depend greatly from the cumulative temperature since the onset of the growing period (Rinne and Nykänen 2000).

Hyrkäs et al. (2018) presented a prediction model of D-value both for primary growth and regrowth grasses. The accuracy of estimated regrowth D-value is weaker compared with primary growth due to variable timing of the first harvest. The model does not include non-climatic factors (such as gras species and variety, plant nutrition), which also may induce variation in D-value.

The difference in predicted and analysed D-values were small in all $\mathrm{H} 1$ silages and the model has been proven to have reasonable accuracy in practise. However, the predictions for the $\mathrm{H} 2$ and $\mathrm{H} 3$ silages were not as good, which reflects both the lack of data and the more complex factors affecting the development of regrowth grass.

Changes in grass digestibility over time are species-dependent, but low temperature generally maintains both low cell wall content (Ford et al. 1979) and high digestibility of grass (Thorvaldsson et al. 2007). The slow decline of in vitro DM digestibility during autumn period has been reported by Kunelius and Narasimhalu (1993). The actual D-values in $\mathrm{H} 2$ and H3 silages were lower than predicted by Hyrkäs et al. (2018) especially in Exp 2 and Exp 3. It is possible that the temperate sum coefficient is too strong in the model.

The growing season 2017 of Exp 3 was rainy and had a low average temperature from late May to September resulting in a temperature sum of $920^{\circ} \mathrm{C}$ in the end of August, which is $160{ }^{\circ} \mathrm{C}$ less than the long-term average in Maaninka, Finland. In Exp 3, visual observations showed dead leaf material in H3. Kykkänen et al. (2016) reported increased amount of dead tissue and fungal diseases caused by prolonged harvest interval between first and second cut in July. The increase of dead plant material was observed especially in meadow fescue which is typically the dominant species in regrowth stands. Dead material itself decreases grass energy content (Kykkänen et al. 2016). However, the energy contents of $\mathrm{H} 3$ were always higher compared with $\mathrm{H} 2$ in the current study. Thus the correlation between dead material and grass energy content seems to be different in second-cut and third-cut grasses.

The fibre content of generative vegetation in first-cut is higher compared with leafy vegetative canopy of regrowth grass, but digestibility and energy concentration are often lower in regrowth compared to primary growth (Virkajärvi and Järvenranta 2001). Fibre has a negative effect on intake so the intake of regrowth grass should be high. The SDMI index includes also other factors (Huhtanen et al. 2007) and has been verified to estimate silage intake potential with good reliability in first-cut and second-cut silages. The SDMI index is based on silage DM, CP and NDF contents, D-value, extent of fermentation (content of fermentation acids) and feed type (primary growth vs. regrowth, forage legume inclusion or whole crop cereal silage inclusion). The modelling of SDMI index included only few experiments conducted with third-cut silages and therefore it is impossible to estimate the coefficients separately for second-cut and third-cut silages (Pang et al. 2019). Feed intake is also affected by psychogenic modulators such as palatability and feed texture (Mertens 1994) but they are not included in the SDMI index.

The DM intake of H3 was exceptionally low in Exp 3. The low DM content of silage decreases intake but chemical composition did not explain the $2.7 \mathrm{~kg} \mathrm{DM}$ intake difference to $\mathrm{H} 1$ and $\mathrm{H} 2$. It is possible that increased proportion of dead tissue decreased the palatability of $\mathrm{H} 3$ silage. The intake of second-cut and third-cut grass silage has been reported to be at the same level (Huuskonen and Pesonen 2017, Pang et al. 2021) or lower (Peoples and Gordon 1989, Sairanen et al. 2016) despite of higher SDMI index of third-cut silage compared with second-cut. The current study also indicated that the SDMI index overestimated the intake of third-cut silage. Variable length and growing conditions of the growing period prior to third-cut makes it difficult to create a reliable model to predict accurately the intake of autumn-cut silage. 
The palatability of silage affects the total DM intake differently in TMR and separate concentrate feeding strategies. The low palatability of regrowth silages in TMR feeding also decreases concentrate intake as seen in Exp 2 and Exp 3. In the case of separate concentrate feeding, decreased silage intake would increase the proportion of concentrate in the diet as observed in Exp 1 where the highest diet energy content of H3 partially compensated for the low silage intake. Despite of this the ME intake was 6.0 MJ lower with $\mathrm{H} 3$ compared with $\mathrm{H} 1$, which corresponds to an energy requirement of $1 \mathrm{~kg} \mathrm{ECM} \mathrm{d}^{-1}$ (Luke 2021).

Regrowth silages, especially H3, are low in NDF and this combined with high concentrate proportion increases the risk of rumen acidosis (Plaizier et al. 2008). In the current study the proportion of silage NDF intake (= estimate

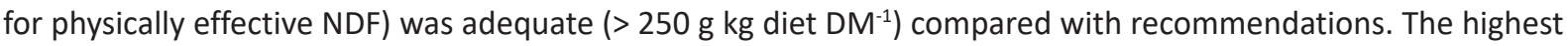
concentrate proportion with $\mathrm{H3}\left(500 \mathrm{~g} \mathrm{~kg} \mathrm{DM}^{-1}\right)$ did not decrease milk fat content so it is unlikely that the cows would have suffered from rumen acidosis.

The high diet energy content together with low NDF content (484 $\mathrm{g} \mathrm{kg} \mathrm{DM}^{-1}$ in the Valio dataset) should maintain both high intake and milk production in diets based on third-cut silages. However, first-cut silage has consistently been reported to produce higher milk yield compared with regrowth silages if the energy content of silages is comparable (Heikkilä et al. 1998, Kuoppala et al. 2008, Pang et al. 2019, Pang et al. 2021). The current study is mainly in line with the previous findings. In Exp 1 the differences in milk yield were relatively small despite of the lowest silage energy content in $\mathrm{H} 2$. The chemical composition of the silages did not explain the difference so the result may be a consequence of random variation.

In Exp 2 the high milk fat content in $\mathrm{H} 1$ resulted in the highest ECM production. The effect of harvest time on milk fat content was not clear but typically first cut maintains milk constituents compared with regrowth harvests (Kuoppala et al. 2008, Pang et al. 2019).

The energy content based on in vitro digestibility was higher in $\mathrm{H} 3$ compared with $\mathrm{H} 2$ in all three experiments. Despite this the average ECM production in H3 diets was lower than based on H2. However, Exp 2 showed that H3 can also maintain high milk production. According to Sairanen et al. (2016) and Pang et al. (2021), feeding of a third-cut silage has improved milk yield compared with a typical second-cut silage. The length of regrowth period partly explains the variable results. Prolonged regrowth period of H3 can be linked with impaired milk production potential.

There were no clear differences in feed efficiency (kg ECM/kg DM intake) between experimental silages. Numerically the highest efficiency was observed with $\mathrm{H} 3$ silages. This is in line with earlier results reported by Sairanen et al. (2016) and Pang et al. (2021). These studies included four independent comparisons between harvests and in every case the feed efficiency was statistically or numerically highest with third-cut silage.

The milk energy output decreased less than ME intake resulting in increased apparent ME utilization with regrowth silages. On the other hand, the ME balance was either numerically or statistically highest with first-cut silages (Table 5). High feed efficiency is in general desirable both economically and environmentally. However, the value of milk ( 35 cent $^{-1}$ ) is much higher compared with average production cost of feed ( 20 cent $\mathrm{kg}^{-1} \mathrm{DM}$ ) resulting in decreased income/feed cost ratio with regrowth silages especially in Exp 3.

Pang (2018) stated that energy is directed into milk production instead of body tissues with regrowth silages which increases apparent feed efficiency. This is supported by the increased body weight gain with $\mathrm{H} 1 \mathrm{compared}$ to $\mathrm{H} 2$ and $\mathrm{H} 3$ in Exp 1 and Exp 2.

It seems clear that silages made of primary growth have higher intake potential than regrowth silages, and thirdcut silages harvested towards the end of the growing season have a particularly high risk of reduced intake potential. Reduced intake leads to prolonged risk of postpartum negative energy balance and increased risk of metabolic diseases (Esposito et al. 2014). Thus silages such as H3 in Exp 3 are not well suited for early lactation cows.

\section{Conclusions}

The results demonstrated the variable quality of regrowth silages. Compared to silage DM concentration and analysed feed values, the intake of third-cut silages was lower than expected. Laboratory analyses could not explain this so the reason may be related to palatability or feed texture of autumn harvested silage, which may be related 
to the long regrowth period under humid conditions. Due to the risk of low intake potential of third-cut silages, they are not recommended for cows in early lactation if there are other silages available.

\section{Acknowledgements}

We gratefully acknowledge the financial support of the Centre for Economic Development, Transport and the Environment for Northern Savolax, Finland (NuRa project, Grant number 10640/2015).

\section{References}

AOAC 1990. Official methods of analysis. Association of Official Analytical Chemists, Inc., Arlington, VA, USA. ISBN 0-935584-42-0.

Esposito, G., Irons, P., Webb, E. \& Chapwanya, A. 2014. Interactions between negative energy balance, metabolic diseases, uterine health and immune response in transition dairy cows. Animal Reproduction Science 144: 60-71. https://doi.org/10.1016/j.anireprosci.2013.11.007

Ford, C.W., Morrison, J.M. \& Wilson, J.R. 1979. Temperature effects on lignin, hemicellulose and cellulose in tropical and temperate grasses. Australian Journal of Agricultural Research 30: 621-633. https://doi.org/10.1071/AR9790621

Haacker, K., Block, H.J. \& Weissbach, F. 1983. Zur kolorimetrischen Milchsäurebestimmung in Silagen mit p-Hydroxydiphenyl. (On the colorimetric determination of lactic acid in silages with p-hydroxydiphenyl). Archiv für Tierernährung 33: 505-512. https://doi.org/10.1080/17450398309425704

Heikkilä, T., Toivonen, V. \& Huhtanen, P. 1998. Effect of spring and autumn silage, protein and concentrate level on milk production. In: Nagy, G. \& Peto, K. (eds.). Ecological Aspects of Grassland Management. Proceedings of the 17th General Meeting of the European Grassland Federation, in May in Debrecen, Hungary. p. 717-721.

Huhtamäki, T. 2020. Ruokinta tuotosseurantatiloilla vuonna 2019. (Feeding of herds in milk recording scheme in 2019). In: Results seminar of milk production. ProAgria Centre of Rural Advisory Centres. Accessed 6 Jan 2021. https://proagria.fi/sites/default/ files/attachment/tuse_karjojen_rehustus_vuonna_2019_huhtamak.pdf. (in Finnish).

Huhtanen, P., Blauwiekel, R. \& Saastamoinen, I. 1998. Effects of intraruminal infusions of propionate and butyrate with two different protein supplements on milk production and blood metabolites in dairy cows receiving grass silage based diet. Journal of the Science of Food and Agriculture 77: 213-222. https://doi.org/10.1002/(SICl)1097-0010(199806)77:2<213::AID-JSFA28>3.0.CO;2-6

Huhtanen P., Nousiainen, J. \& Rinne, M. 2006. Recent developments in forage evaluation with special reference to practical applications. Agricultural and Food Science 15: 293-323. https://doi.org/10.2137/145960606779216317

Huhtanen, P., Rinne, M. \& Nousiainen, J. 2007. Evaluation of the factors affecting silage intake of dairy cows: a revision of the relative silage dry-matter intake index. Animal 1: 758-770. https://doi.org/10.1017/S175173110773673X

Huuskonen, A. \& Pesonen, M. 2017. A comparison of first-, second-and third-cut timothy silages in the diets of finishing beef bulls. Agricultural and Food Science 26: 16-24. https://doi.org/10.23986/afsci.60413

Hyrkäs, M., Korhonen, P., Pitkänen, T., Rinne, M. \& Kaseva, J. 2018. Grass growth models for estimating digestibility and dry matter yield of forage grasses in Finland. In: B. Horan, B., Hennessy, D., O’Donovan, M., Kennedy, E., McCarthy, B., Finn, J.A. \& O’Brien, B. (eds.). Sustainable Meat and Milk Production from Grasslands. Proceedings of the 27th General Meeting of the European Grassland Federation, in June in Cork, Ireland. Grassland Science in Europe 23: 252-254.

Hyrkäs, M., Sairanen, A., Kykkänen, S., Virkajärvi, P. \& Isolahti, M. 2015. Different harvesting strategies and cultivar mixtures for grass silage production in Finland. In: van den Pol-van Dasselaar, A., Aarts, H.F.M., De Vliegher, A., Elgersma, A., Reheul, D., Reijneveld, J.A., Verloop, J. \& Hopkins, A. (eds.).Grassland and forages in high output dairy farming systems. Proceedings of the 18th symposium of the European Grassland Federation, in June in Wageningen, the Netherlands. Grassland Science in Europe 20: 239-241.

Kunelius, H.T. \& Narasimhalu, P.R. 1993. Effect of autumn harvest date on herbage yield and composition of grasses and white clover. Field Crops Research 31: 341-349. https://doi.org/10.1016/0378-4290(93)90072-U

Kuoppala, K., Rinne, M., Nousiainen, J. \& Huhtanen, P. 2008. The effect of cutting time of grass silage in primary growth and regrowth and the interactions between silage quality and concentrate level on milk production of dairy cows. Livestock Science 116: 171-182. https://doi.org/10.1016/j.livsci.2007.10.002

Kykkänen, S., Virkajärvi, P., Hyrkäs, M. \& Parikka, P. 2016. The role of fungal diseases in the accumulation of dead tissue in timothy and meadow fescue swards. In: Höglind, M., Bakken, A.K., Hovstad, K.A., Kallioniemi, E., Riley, H., Steinshamn, H. \& Østrem, L. (eds.). The multiple roles of grassland in the European bioeconomy. Proceedings of the 21th General Meeting of the European Grassland Federation, in September in Trondheim, Norway. Grassland Science in Europe 21. p. 492-494.

Luke 2021. Feed Tables and Nutrient Requirements. Natural Resources Institute Finland, Jokioinen, Finland. www.luke.fi/feedtables. Accessed on 8 January 2021.

McCullough, H. 1967. The determination of ammonia in whole blood by direct colorimetric method. Clinica Chimica Acta 17: 297-304. https://doi.org/10.1016/0009-8981(67)90133-7

Mertens, D.R. 1994. Regulation of forage intake. In: Fahey Jr, G.C. (ed.). Forage quality, evaluation, and utilization. American Society of Agronomy, Inc., Crop Science Society of America, Inc., and Soil Science Society of America, Inc. Madison, Wisconsin, USA. p. 450-493.

Nousiainen, J., Rinne, M., Hellämäki, M. \& Huhtanen, P. 2003. Prediction of the digestibility of the primary growth of grass silages harvested at different stages of maturity from chemical composition and pepsin-cellulase solubility. Animal Feed Science and Technology 103: 97-111. https://doi.org/10.1016/S0377-8401(02)00283-3 
Pang, D. 2018. Improved utilisation of grass silage in milk production. Harvesting strategy and feeding value. Doctoral thesis. Swedish University of Agricultural Sciences, Umeå. https://pub.epsilon.slu.se/15654/1/Pang_D_180913.pdf

Pang, D., Krizsan, S., Sairanen, A., Nousiainen, J. \& Huhtanen, P. 2019. Modelling feed intake and milk yield responses to different grass ley harvesting strategies. Grass and Forage Science 74: 509-524. https://doi.org/10.1111/gfs.12425

Pang, D., Yan, T. \& Krizsan, S. 2021. Effect of strategy for harvesting regrowth grass silage on performance in dairy cows. Journal of Dairy Science 104: 367-380. https://doi.org/10.3168/jds.2020-18888

Peoples, A. \& Gordon, F. 1989. The influence of wilting and season of silage harvest and the fat and protein concentration of the supplement on milk production and food utilization by lactating cattle. Animal Science 48: 305-317. https://doi.org/10.1017/\$0003356100040307

Plaizier, J.C., Krause, D.O., Gozho, G.N. \& McBride, B.W. 2008. Subacute ruminal acidosis in dairy cows: The physiological causes, incidence and consequences. The Veterinary Journal 176: 21-31. https://doi.org/10.1016/j.tvjl.2007.12.016

Rinne, M., Jaakkola, S., Kaustell, K., Heikkilä, T. \& Huhtanen, P. 1999. Silages harvested at different stages of grass growth versus concentrate foods as energy and protein sources in milk production. Animal Science 69: 251-263. https://doi.org/10.1017/S1357729800051286

Rinne, M. \& Nykänen, A. 2000. Timing of primary growth harvest affects the yield and nutritive value of timothy-red clover mixtures. Agricultural and Food Science in Finland 9: 121-134. https://doi.org/10.23986/afsci.5654

Sairanen, A., Palmio, A. \& Rinne, M. 2016. Milk production potential of regrowth grass silages. In: The multiple roles of grassland in the European bioeconomy. Proceedings of the 21th General Meeting of the European Grassland Federation, in September in Trondheim, Norway. Grassland Science in Europe 21. p. 379-381.

Sjaunja, L.O., Baevre, L., Junkkarinen, L., Pedersen, J. \& Setälä J. 1990. A Nordic proposal for an energy corrected milk (ECM) formula. In: Gaillon, P. \& Chabert, Y. (eds.). Proceedings of the 27th session of International Committee of Recording and Productivity of Milk Animal. Paris, France. p. 156-157.

Somogyi, M. 1945. A new reagent for the determination of sugars. Journal of Biological Chemistry 160: 61-68. The equipment used was Schimadzu double-beam UV-VIS spectrophotometer UV-1800 (Schimadzu Co.,Kyoto, Japan). https://doi.org/10.1016/S0021-9258(18)43097-9

Thorvaldsson, G., Tremblay, G.F. \& Kunelius, H.T. 2007. The effects of growth temperature on digestibility and fibre concentration of seven temperate grass species. Acta Agriculturae Scandinavica Section B: Soil and Plant Science 57: 322-328. https://doi.org/10.1080/09064710600984221

Van Soest, P.J., Robertson, J.B. \& Lewis, B.A. 1991. Methods for dietary fiber, neutral detergent fibre and nonstarch polysaccharides in relation to animal nutrition. Journal of Dairy Science 74: 3583-3597. https://doi.org/10.3168/jds.S0022-0302(91)78551-2

Virkajärvi, P. \& Järvenranta, K. 2001. Leaf dynamics of timothy and meadow fescue under Nordic conditions. Grass and Forage Science 56: 294-304. https://doi.org/10.1046/j.1365-2494.2001.00276.x 